\title{
The growth of GaN on the metallic compound graphite substrate by HVPE
}

\author{
Ji Young Kim, Gang Seok Lee, Min Ah Park, Min Jeong Shin, Sam Nyung Yi, Min Yang, Hyung \\ Soo $\mathrm{Ahn}^{\dagger}$, Young Moon Yu*, Suck-Whan Kim**, Hyo Suk Lee***, Hee Shin Kang****, Hun Soo \\ Jeon***** and Nobuhiko Sawaki****** \\ Department of Applied Sciences, Korea Maritime University, Busan 606-791, Korea \\ *LED-MCT R\&BD Center at Pukyong National University, Busan 608-737, Korea \\ **Department of Physics, Andong National University, Andong 760-749, Korea \\ ***L\&L.Co., Ltd., Suwon, 443-470, Korea \\ ****CSsol.Co., Ltd., Busan 619-961, Korea \\ *****Department of Electrical Engineering and Computer Sciences, Nagoya University, Nagoya 464-8603, Japan \\ ******Department of Electrical and Electronics Engineering, AIT, Toyota, Aichi 470-0392, Japan
}

(Received August 29, 2013)

(Revised September 17, 2013)

(Accepted September 27, 2013)

\begin{abstract}
The GaN layer was typical III-V nitride semiconductor and was grown on the sapphire substrate which cheap and convenient. However, sapphire substrate is non-conductivity, low thermal conductivity and has large lattice mismatch with the $\mathrm{GaN}$ layer. In this paper, the poly GaN epilayer was grown by HVPE on the metallic compound graphite substrate with good heat dissipation, high thermal and electrical conductivity. We tried to observe the growth mechanism of the GaN epilayer grown on the amorphous metallic compound graphite substrate. The $\mathrm{HCl}$ and $\mathrm{NH}_{3}$ gas were flowed to grow the GaN epilayer. The temperature of source zone and growth zone in the HVPE system was set at $850^{\circ} \mathrm{C}$ and $1090^{\circ} \mathrm{C}$, respectively. The GaN epilayer grown on the metallic compound graphite substrate was observed by SEM, EDS, XRD measurement.
\end{abstract}

Key words GaN, Graphite, HVPE, EDS, SEM, XRD

\section{HVPE 방법에 의한 금속 화합물 탄소체 기판 위의 GaN 성장}

김지영, 이강석, 박민아, 신민정, 이삼녕, 양민, 안형수 ${ }^{\dagger}$, 유영문*, 김석환**, 이효석***, 강희신****, 전헌수*****, Nobuhiko Sawaki******

한국해양대학교 응용과학과, 부산, 606-791

*부경대학교 LED해양융합기술연구센터, 부산, 608-739

**안동대학교 물리학과, 안동, 760-749

***L\&L.Co., Ltd., 수원, 443-470

*****CSsol.Co., Ltd., 부산, 619-961

*****나고야대학교 전자공학 및 컴퓨터 과학과, 나고야, 464-8603, 일본

******AIT 전기전자공학과, 아이치, 470-0392, 일본

(2013년 8월 29일 접수)

(2013년 9월 17일 심사완료)

(2013년 9월 27일 게재확정)

요 약 $\mathrm{GaN}$ 는 대표적인 $\mathrm{III}-\mathrm{V}$ 족 질화물반도체로 주로 값싸고 다루기 쉬운 사파이어 기판 위에 성장된다. 하지만 사파 이어 기판은 부도체이며, $\mathrm{GaN}$ 과의 격자부정합을 일으키고 열전도도 또한 낮은 기판으로 알려져 있다. 본 논문에서는 방열 기능과 열 - 전기전도도가 뛰어난 금속 화합물 탄소체 기판 위에 poly GaN epilayer를 HVPE법으로 성장시켜보았다. 비정질 의 금속 화합물 탄소체 기판위에 성장되는 $\mathrm{GaN}$ epilayer의 성장메카니즘을 관찰하였다. GaN epilayer의 성장을 위해 $\mathrm{HCl}$ 과 $\mathrm{NH}_{3}$ 를 흘려주었다. 성장하기 위해 source zone과 growth zone의 온도는 각각 $850^{\circ} \mathrm{C}$ 와 $1090^{\circ} \mathrm{C}$ 로 설정했다. 성장이 끝난 샘 플은 $\mathrm{SEM}, \mathrm{EDS}, \mathrm{XRD}$ 측정을 통해 분석하였다.

\footnotetext{
Corresponding author

Tel: +82-51-410-4781

Fax: +82-51-410-4780

E-mail: ahnhs@hhu.ac.kr
} 


\section{1. 서 론}

$\mathrm{GaN}$ 나 $\mathrm{AlN}$ 과 같이 직접천이형의 넓은 에너지 밴드갭 을 가진 III-V족 질화물반도체에 대한 연구가 활발해지 면서 가시광선영역뿐만 아니라 자외선영역까지 가지는 $\mathrm{LED}$ 와 고 이동도 트랜지스터, 고온 및 고출력 전자소자 등에 응용이 매우 활발해졌다[1-5]. 대부분의 III-V족 질 화물반도체는 주로 사파이어 기판 위에 성장시킨다. 사 파이어기판은 다른 기판에 비해 비교적 구하기가 쉽고 가격이 저렴하여 III족 질화물반도체 성장에 자주 이용 된다[6, 7]. 하지만 $\mathrm{GaN}$ 기반의 epi layer와 기판과의 격자부정합으로 인해 높은 결함밀도(dislocation density) 가 발생되고 이로 인한 응력으로 인해 압전분극도 생길 수 있으며, 기판자체가 부도체의 성질을 가지고 있으며, 열전도성도 매우 낮은 문제점들이 있다[8-13]. 특히 낮은 열전도성은 고온에서 동작하는 전자소자 및 많은 양의 열이 발생되는 고휘도 $\mathrm{LED}$ 와 고출력 전자소자에 치명 적인 단점이다. 소자 내부에서 발생된 열은 전자의 움직 임을 방해할 뿐만 아니라 발광되는 빛의 파장대에도 영 향을 끼친다. 그래서 소자의 광학적, 전기적 성질에 영향 을 끼치는 방열문제에 대해 많은 연구가 이뤼지고 있다 $[14,15]$.

금속 화합물 탄소체 기판은 다공성의 탄소체(graphite) 구조에 비철금속을 고온 - 고압에서 주입하여 만든 기판 이다. 비철금속으로는 주로 구리, 알루미늄, 아연, 주석, 니켈, 금, 은 등이 있으며, 본 논문에서는 약 $15 \%$ 의 구 리가 사용되었다. 탄소들로 이뤄진 탄소체는 기판의 형 태를 유지하며, 탄소와 탄소 사이에 미세한 구멍들이 형 성되어 있고, 미세한 구멍에 비철금속인 구리가 함침되 어 있는 형태이다. 주입된 비철금속은 반도체가 금속 화 합물 탄소체 기판에 성장할 수 있도록 도와준다. 이렇게 만들어진 금속화합물탄소체 기판은 비철금속이 탄소체구 조에 함유됨으로써, 높은 열팽창율과 열전도성을 가지고, 전도체의 성질을 지닌다. 그래서 금속화합물탄소체 기판 을 사용한 소자는 일반 사파이어 기판을 사용한 소자에 비해 방열기능이 뛰어나 고온에서 작동하기 용이하고, 많은 양의 열이 발생되더라도 소자의 성능에 열적인 영 항을 크게 끼치지 않게 할 수 있다. 부가적으로 탄소체 와 금속으로 이뤄진 기판은 보다 높은 전기전도성을 가 지므로 보다 쉬운 전극형성이 이뤼질 수 있다.

본 논문에서는 비정질(amorphous)구조의 금속 화합물 탄소체 기판 위에 poly $\mathrm{GaN}$ epilayer를 성장시킴으로써, 차후 에피와 heat sink 소재의 일체형 기판으로서의 응 용 가능성을 조사하며, 성장 조건의 최적화에 의해 향상 된 결정질을 가진 epilayer를 통한 소자의 구현을 달성 하기 위한 기초 실험을 하였다. 나아가 비정질을 가지는 기판 위에 결정질이 우수한 질화물반도체를 성장시키는
것을 최종 목표로 하였다. 결정질을 향상시키기 위해 저 온에서부터 성장을 시작하여 비철금속과 반도체간의 반 응성을 높였으며, 성장시간과 온도에 따라 seed layer, buffer layer가 순서대로 형성되고, 마지막에 질화물반도 체 층이 형성될 수 있도록 하였다. 마지막으로 $\mathrm{SEM}$ 을 통해서 금속 화합물 탄소체 기판의 형태와 질화물반도체 의 성장에 중요한 역할을 하는 seed를 관찰하고, $\mathrm{EDS}$ 와 $\mathrm{XRD}$ 를 통해 성장된 질화물반도체의 결정질과 성분을 알아보았다.

\section{2. 실험방법}

본 논문에서는 방열기능이 뛰어난 기판에 III-V족 질 화물반도체인 $\mathrm{GaN}$ epilayer를 HVPE 방법으로 성장시켜 보았다. 대부분의 질화물반도체는 MOCVD를 이용하여 성장하지만 본 논문에서는 빠른 증착속도를 가진 $\mathrm{HVPE}$ 를 이용하여 비교적 불순물 농도가 낮은 epilayer를 성 장시켜 보았다. HVPE는 크게 source zone과 growth zone으로 나눠지는데, source zone에는 3족 금속인 $\mathrm{Ga}$ 이 들어가고, growth zone에서는 성장시킨 금속 화합물 탄소체 기판이 들어가게 된다. 이 growth zone에서 $\mathrm{GaN}$ epilayer가 성장되고, 두 개의 zone은 독립적으로 온도를 설정할 수 있다. Source zone의 온도는 약 850로 설정 하고 growth zone의 온도는 $1090^{\circ} \mathrm{C}$ 으로 설정하였다. 실 험이 진행되는 동안 석영(quartz)으로 이뤄진 반응관들의 내부가 안정된 분위기를 가질 수 있도록 $\mathrm{N}_{2}$ 를 지속적으 로 흘려주었다. Source zone에는 3족 금속인 Ga과 반응 하여 $\mathrm{GaCl}$ 을 만들기 위한 $\mathrm{HCl}$ 을 흘려주었으며, growth zone에는 $\mathrm{NH}_{3}$ 를 흘려주어 source zone에서 형성된 $\mathrm{GaCl}$ 과 반응하여 최종적으로 $\mathrm{GaN}$ 가 형성되도록 하였다. 이 때 각각의 기체에 대한 캐리어가스로는 $\mathrm{N}_{2}$ 가 사용되었 다. 가열을 시작하여 Growth zone의 온도가 $100^{\circ} \mathrm{C}$ 가 되면 기판의 nitridation을 위해 $\mathrm{NH}_{3}$ 를 약 $5000 \mathrm{sccm}$ 정 도 흘려주고, $200^{\circ} \mathrm{C}$ 가 되었을 때 $\mathrm{GaCl}$ 형성을 위해 $\mathrm{HCl}$ 을 약 $100 \mathrm{sccm}$ 정도 source zone에 흘려주었다. 그 리고 온도가 약 $500^{\circ} \mathrm{C}$ 에 다다르게 되면, 금속 화합물 탄소체 기판 안에 있는 비철금속인 구리가 결정화 되기 시작하였다. 비철금속이 결정화되는 온도는 금속에 따라 각각 다른 값을 가진다. 비철금속이 결정화되기 시작하 면서 $\mathrm{GaN}$ epilayer가 형성될 수 있는 환경이 되었다. $500^{\circ} \mathrm{C}$ 정도의 낮은 온도에서부터 점점 온도를 올려 seed layer와 buffer layer을 차례대로 성장시켰다. 이때 $\mathrm{GaCl}+\mathrm{NH}_{3}+\mathrm{Cu}$ 가 결합된 결정이 만들어 지게 되고, 이는 $\mathrm{GaN}$ epilayer의 성장에 매우 중요한 seed 역할을 하게 된다.

Growth zone의 온도가 설정된 $1090^{\circ} \mathrm{C}$ 가 되어 안정화 
가 이루어지고 본격적으로 $\mathrm{GaN}$ epilayer의 성장이 이루 어졌다. source zone의 온도는 이미 $850^{\circ} \mathrm{C}$ 으로 안정화가 되어 있었다. 성장시간은 growth zone의 온도가 $1090^{\circ} \mathrm{C}$ 가 되어 안정화가 된 순간부터 한 시간 성장하였다.

\section{3. 실험결과 및 고찰}

금속 화합물 탄소체 기판의 SEM사진들을 Fig. 1에 나타내었다. Fig. 1(a)는 열처리공정만 진행한 기판의 모 습이다. 기판을 제작할 때 탄소체 사이에 주입되었던 비 철금속인 구리가 높은 온도에서 결정화되어 밖으로 나온 것을 볼 수 있다. 결정화된 구리는 $\mathrm{GaN}$ epilayer의 성장 에 매우 중요한 역할을 한다. Fig. 1(b)는 성장이 완료된 기판의 전체모습이다. 비정질구조에 성장된 $\mathrm{GaN}$ epilayer 들은 전체적으로 flat한 모양을 가지지 못하고 서로 다른 방향성을 가지고 성장된 poly 형태로 성장되었다. EDS 측정을 통해 열처리된 기판의 성분과 성장이 끝난 기판
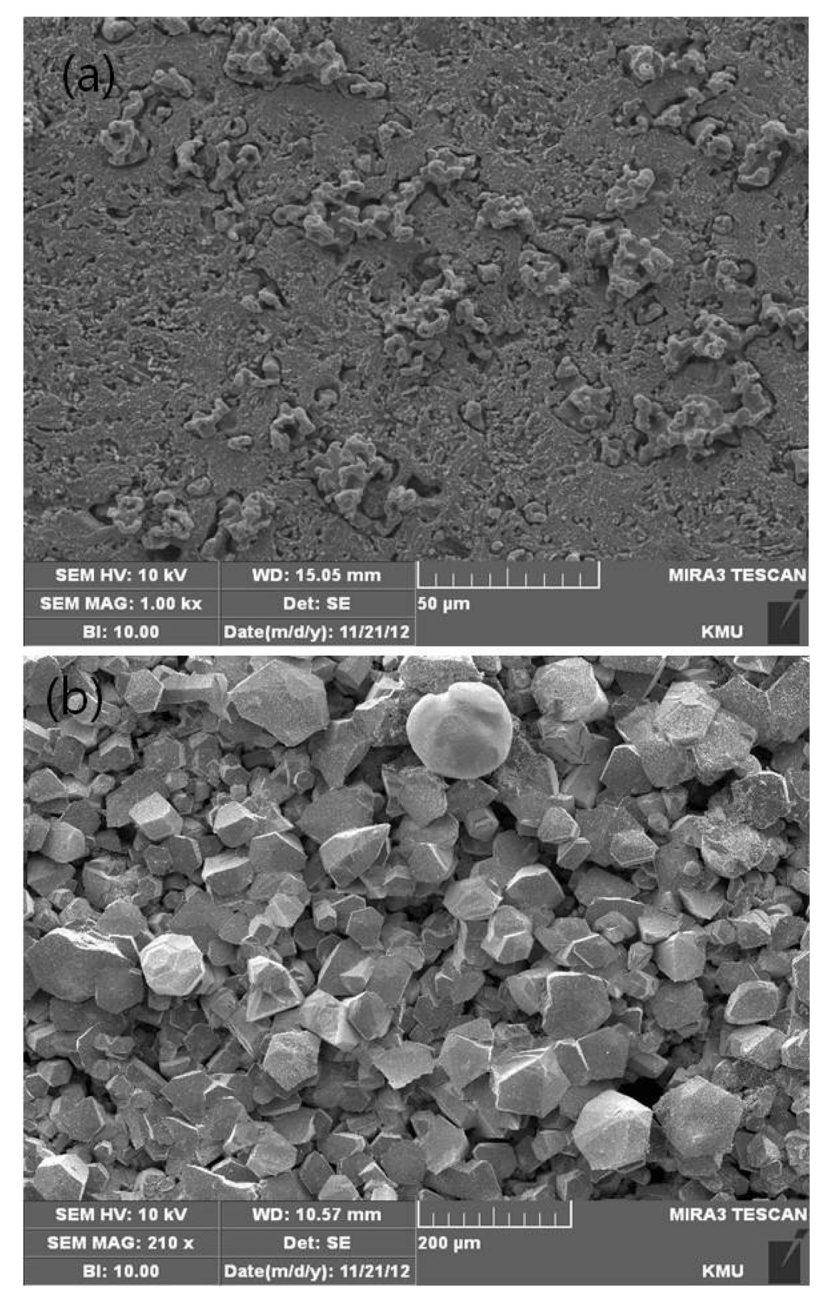

Fig. 1. The SEM images of the metallic compound graphite substrate (a) after heat treatment and (b) after the growth.
의 성분에 대해 알아 볼 것이다. Fig. 2(a)와 Fig. 2(b)는 $\mathrm{GaN}$ epillayer의 성장에 매우 중요한 역할을 하는 seed 의 모습이다. Fig. 2(a)의 모습은 둥근 형태를 지니고 있 고, Fig. 2(b)의 모습은 Fig. 2(a)의 모습에 비해 육각형 의 각진 모습을 볼 수 있다.

Fig. 3은 위에서 설명한 SEM사진을 토대로 EDS측정 을 한 결과들이다. Fig. 3(a)와 Fig. 3(b)는 열처리된 기 판의 각 부분에 point scan으로 측정한 것이다. Fig. 3(a)의 경우에는 기판부분에 point scan하여 측정한 결과 이다. 금속 화합물 탄소체 기판의 형태를 이루고 있는 탄소체와 같은 탄소성분이 가장 많이 측정되었다. Fig. 3(b)의 경우에는 기판에 존재하는 결정체에 point scan을 한 결과이다. 탄소체의 미세한 구멍 사이에 있던 비철금 속인 구리가 일정 온도에서 결정화가 되어 밖으로 나온 것을 볼 수 있었다. 결정체의 성분 또한 $\mathrm{Cu}$ 가 주로 관 측되었다. 이 결정체는 $\mathrm{Ga}$ 과 만나 $\mathrm{GaN}$ epilayer의 성장 에 중요한 seed 역할을 하게 된다. 성장온도가 점점 증 가함에 따라 구리의 결정화가 좀더 활발해지고, $\mathrm{GaN}$ 의
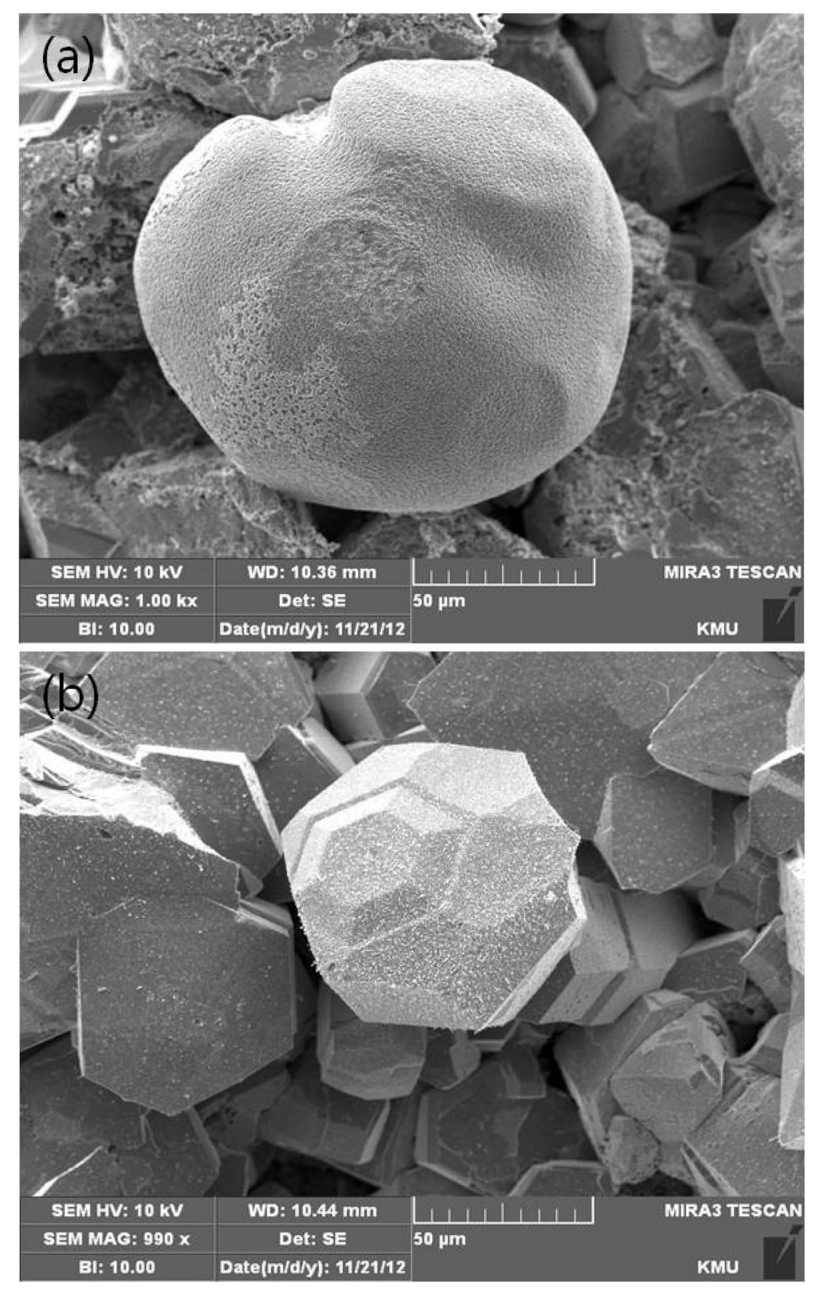

Fig. 2. The SEM images of the seed which very important to the growth of $\mathrm{GaN}$ epilayer. 

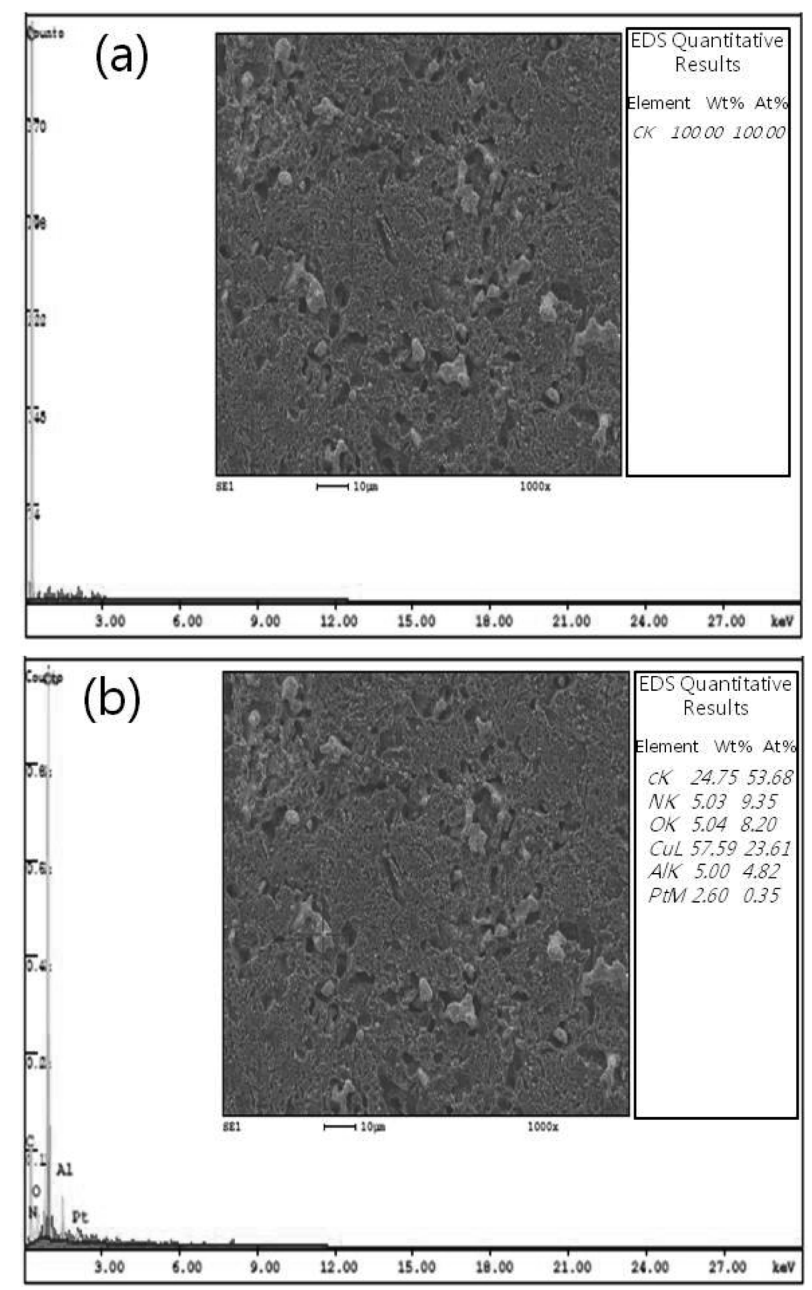

Fig. 3. EDS measurement results of (a) the metallic compound graphite substrate and (b) $\mathrm{Cu}$ crystal on the metallic compound graphite substrate.

성장조건에 알맞은 온도에 가까워 질수록 seed의 성분은 $\mathrm{Cu}$ 에서 $\mathrm{Ga}$ 으로 바뀌게 된다. 이런 결과를 잘 나타낸 것 들이 Fig. 4(a)와 Fig. 4(b)이다. Fig. 4(a)는 성장이 완 료된 기판에서 보여진 둥근 형태의 seed를 point scan한 것이다. 측정결과에서 보이는 것처럼 seed의 성분은 $\mathrm{Cu}$ 와 $\mathrm{Ga}$ 이 같이 포함되어 있다는 것을 알 수 있다. Fig. 4(b)의 경우, 육각형의 각진 형태를 가지고 있는 seed를 point scan한 것이다. 마찬가지로 $\mathrm{Cu}$ 와 $\mathrm{Ga}$ 이 같이 포함 되어 있지만 주로 이루어진 구성성분이 차이가 있다. 특 히 seed의 형태에 따라 보았을 때, 비교적 $\mathrm{Ga}$ 의 성분이 적은 seed의 형태는 둥근 형태를 지니고 있었다. 하지만 $\mathrm{Ga}$ 의 성분이 높은 seed는 육각형의 형태를 잘 지니고 있다.

금속 화합물 탄소체 기판이 일정한 온도에서 비철금속 인 구리가 결정화를 이루게 되고, 이 결정체는 $\mathrm{Ga}$ 과 반 응하여 seed로 변하게 된다. 초반에 성장된 $\mathrm{Cu}$ richseed들이 seed layer를 이루게 된다. 성장온도가 증가하
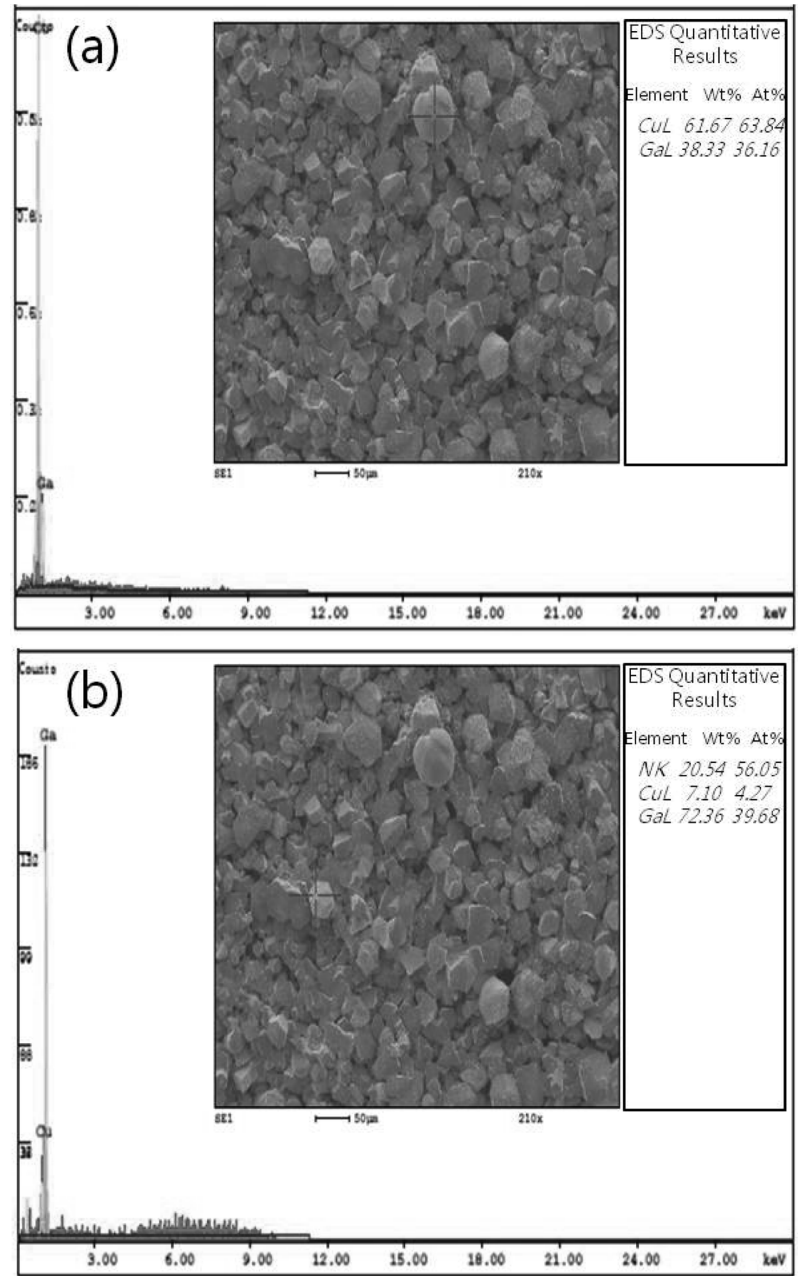

Fig. 4. EDS measurement results of the seed which very important to the growth of $\mathrm{GaN}$ epilayer.

고 안정화됨으로써 $\mathrm{Ga}$ 과의 반응이 더욱 활발해지고 $\mathrm{Ga}$ rich-seed가 성장되고, $\mathrm{Ga}$ 성분이 많아진 seed는 $\mathrm{GaN}$ epilayer의 성장에 도움이 되면서 buffer layer의 역할을 한다. 이 buffer layer를 통해 비정질의 금속 화합물 탄 소체 기판 위에 $\mathrm{GaN}$ epilayer의 성장이 가능해졌다고 볼 수 있다.

Fig. 5는 XRD 측정결과이다. $\mathrm{XRD}$ 는 2 theta-omega mode로 측정하였으며, 그래프에서와 같이 다양한 피크 가 관찰되었다. 특히 그래프 앞쪽에 2 theta값이 $32.3^{\circ}$, $34.5^{\circ}, 36.6^{\circ}$ 로 세가지 피크가 측정되었다. XRD 측정결 과를 $\mathrm{ICDD}$ 카드를 통해서 분석한 결과, $34.5^{\circ}$ 의 피크는 [002] 방향의 $\mathrm{GaN}$ 를 나타내고, $32.3^{\circ}$ 의 피크는 [100] 방 향의 $\mathrm{GaN}$ 를 나타내고, $36.6^{\circ}$ 의 피크는 [101] 방향의 $\mathrm{GaN}$ 를 나타낸다. 또한 그래프 뒤쪽에 있는 피크들은 $57.6^{\circ}, 63.3^{\circ}$ 로 측정되었다. 마찬가지로 $\mathrm{ICDD}$ 카드를 이용 하여 분석한 결과, $57.6^{\circ}$ 는 [110] 방향으로 성장된 $\mathrm{GaN}$ 를 내고, $63.3^{\circ}$ 는 [103] 방향으로 성장된 $\mathrm{GaN}$ 를 나타낸 다. 상대적인 세기를 통해 [110] 방향과 [103] 방향으로 


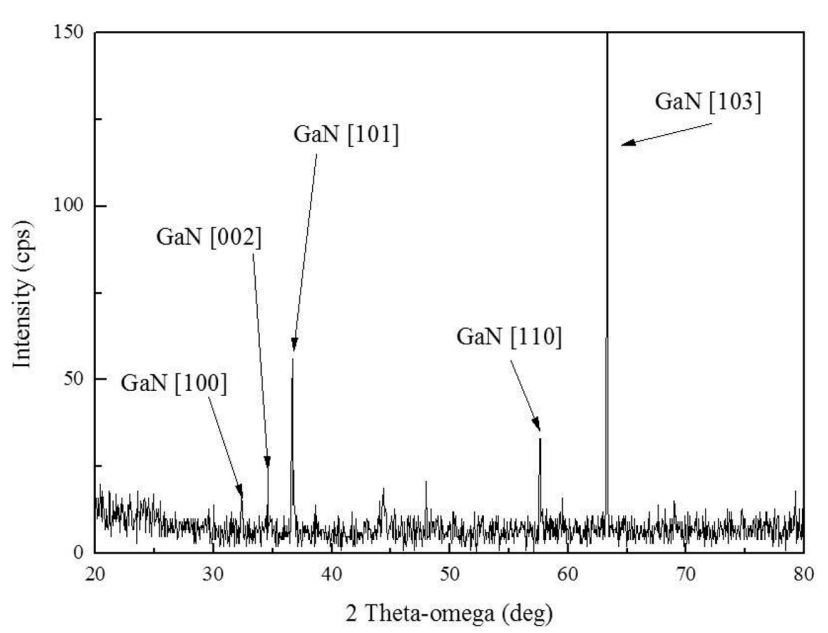

Fig. 5. XRD measurement result of the GaN epilayer grown on the metallic compound graphite substrate.

더 많은 성장이 이루어졌음을 짐작할 수 있다. 이 결과 를 토대로 성장된 $\mathrm{GaN}$ epilayer는 서로 다른 방향성을 가지고 poly 형태로 성장했다는 것을 알 수 있다.

\section{4. 결 론}

비정질의 금속 화합물 탄소체 기판 위에 HVPE 방법 으로 poly 형태의 $\mathrm{GaN}$ epilayer를 성장하였다. 금속 화 합물 탄소체 기판 위에 길러진 $\mathrm{GaN}$ epilayer는 poly 형 태이긴 하나, 성장이 가능함을 알 수 있었다. XRD 측정 을 통해서 다양한 방향을 가진 $\mathrm{GaN}$ epilayer을 관찰할 수 있었고, $\mathrm{EDS}$ 측정을 통해서 금속 화합물 탄소체 기 판을 이루는 성분들에 대해서 알 수 있었다. 또, 성장에 매우 중요한 역할을 하는 $\operatorname{seed}$ 는 $\mathrm{Cu}$ 가 결정화된 결정체 에서부터 시작된다는 것을 알 수 있었다. $\mathrm{Cu}$ 의 결정화 가 활성화되고, 성장온도도 최적화가 되면 $\mathrm{Ga}$ 과의 반응 이 이뤄지면서 점차 육각형의 기둥 형태를 가지는 것을 볼 수 있었다. 차후 지속적인 연구를 통해 방열기능이 뛰어난 금속 화합물 탄소체 기판에 flat한 형태의 $\mathrm{GaN}$ 단결정이 성장가능해지면 매우 혁신적인 기판으로 자리 매김할 것이라 기대된다.

\section{감사의 글}

이 논문은 2012년도 정부(교육과학기술부)의 재원으로 한국연구재단의 기초연구사업 지원을 받아 수행된 것임 (2012R1A1A2000886).

\section{참 고 문 헌}

[ 1] V. Adivarahan, J. Zhang, A. Chitnis, W. Shuai, J. Sun, R. Pachipulusu, M. Shatalov and M. A. Khan, "Submilliwatt power III-N light emitting diodes at $285 \mathrm{~nm}$ ", Jpn. J. Appl. Phys. 41 (2002) 435.

[2] T.G. Zhu, U. Chowdhury, J.C. Denyszyn, M.M. Wong and R.D. Dupuis, "AlGaN/AlGaN UV light-emitting diodes grown on sapphire by metalorganic chemical vapor deposition", J. Cryst. Growth 248 (2003) 548.

[ 3 ] T. Nishida, H. Saito and N. Kobayashi, "Efficient and high-power AlGaN-based ultraviolet light-emitting diode grown on bulk GaN", Appl. Phys. Lett. 79 (2001) 711.

[4] H.M. Kim, J.S. Choi. J.E. Oh and T.K. Yoo, "Cathodoluminescence characterization of $\mathrm{GaN}$ thick films grown by using the HVPE method", J. Korean Phys. Soc. 37 (2000) 956.

[ 5 ] Y.J. Yu, M.Y. Ryu, P.W. Yu, D.J. Kim and S.J. Park, "Optical investigation of $\mathrm{InGaN} / \mathrm{GaN}$ quantum well structures with various barrier widths", J. Korean Phys. 28 (2001) 134.

[6] B. Luo, J. Kim, R. Mehandru, F. Ren, K.P. Lee, S.J. Pearton, A.Y. Polyakov, N.B. Smirnov, A.V. Govorkov, E.A. Kozhukhova, A.V. Osinsky and P.E. Norris, "Comparison of ohmic contact properties on $n-G a N / p-S i C$ and n-AlGaN/p-SiC heterojunctions", Solid-State Electron 46 (2002) 1345.

[7] F. Yun, M.A. Reshchikov, K. Jones, P. Visconti, H. Morkoç, S.S. Park and K.Y. Lee, "Electrical, structural, and optical characterization of free-standing GaN template grown by hydride vapor phase epitaxy", SolidState Electron 44 (2000) 2225.

[ 8 ] T. Ueda, M. Ishida and M. Yuri, "Laser lift-off of very thin AlGaN film from sapphire using selective decomposition of GaN interlayer", Appl. Surf. Sci. 216 (2003) 512.

[9] A. Koukitu, F. Satoh, T. Yamane, H. Murakami and Y. Kumagai, "HVPE growth of $\mathrm{Al}_{\mathrm{x}} \mathrm{Ga}_{1-\mathrm{x}} \mathrm{N}$ ternary alloy using $\mathrm{AlCl}_{3}$ and $\mathrm{GaCl}$ ", J. Cryst. Growth 305 (2007) 335.

[10] S.N. Lee, H.S. Paek, J.K. Son, T. Sakong, E. Yoon, O.H. Nam and Y. Park, "Growth of InGaN multiple quantum wells and GaN eplilayer on GaN substrate", Physica B 376-377 (2006) 532.

[11] K. Kawasaki, C. Koike, Y. Aoyagi and M. Takeuchi, "Vertical AlGaN deep ultraviolet light emitting diode emitting at $322 \mathrm{~nm}$ fabricated by the laser lift-off technique”, Appl. Phys. Lett. 89 (2006) 261114.

[12] J.K. Kang and Y.J. Kim, "Fabrication and characterization of tilted R-plane sapphire wafer for nonpolar aplane GaN", J. Korean Cryst. Growth \& Cryst. Tech. 21(5) (2011) 187.

[13] D.K. Oh, B.G. Choi, S.H. Kang, S.Y. Kim, S.A. Kim, S.K. Lee, J.H. Chung, K.H. Kim and K.B. Shim, "Surface morphology variation during wet etching of $\mathrm{GaN}$ epilayer grown by HVPE", J. Korean Cryst. Growth \& Cryst. Tech. 22(6) (2012) 261.

[14] H.H. Wu, K.H. Lin and S.T. Lin, "A study on the heat dissipation of high power multi-chip COB LEDs", Microelectr. J. 43 (2012) 280.

[15] H.H. Cheng, D.S. Huang and M.T. Lin, "Heat dissipation design and analysis of high power LED array using the finite element method", Microelectron. Reliab. 52 (2012) 905. 